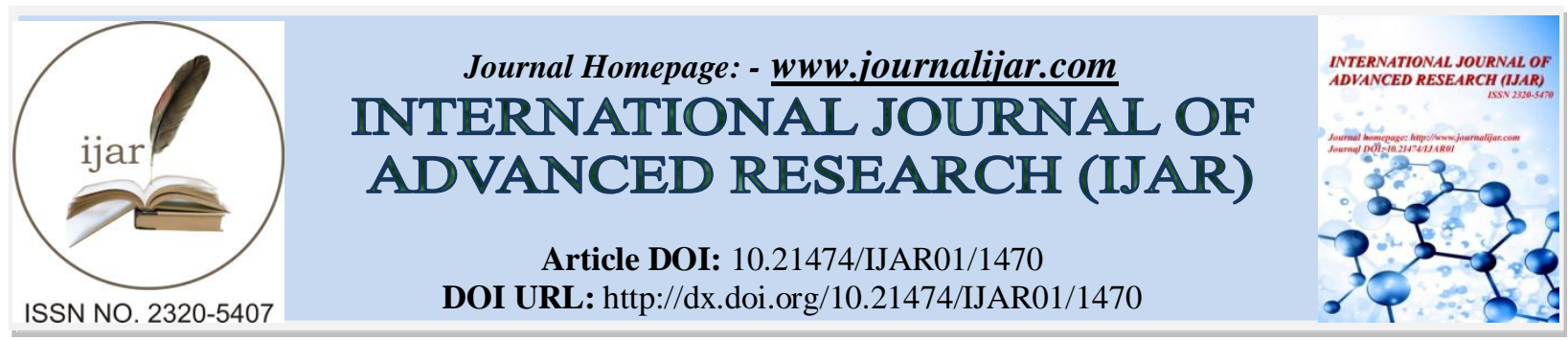

RESEARCH ARTICLE

\title{
SOCIO-ECONOMIC DEVELOPMENT THROUGH THE INDIAN GOVERNMENT SCHEME - MGNREGA: A REVIEW ON WEST BENGAL STATE.
}

\section{Dr. Mafruza Sultana ${ }^{1}$ and Dr. K.S. Srinivasa Rao ${ }^{2}$.}

1. Research and Teaching Associate, IFIM Business School, Bangalore.

2. Dean - Academics, IFIM Business School, Bangalore.

\section{Manuscript Info}

Manuscript History

Received: 12 July 2016

Final Accepted: 26 August 2016

Published: September 2016

Key words:-

Women Empowerment, Gender

Inequality, Socio-Economic

Development, MGNREGA

\section{Abstract}

The Mahatma Gandhi National Rural Employment Guarantee Act (MGNREGA), the Indian Government Scheme which entitles rural households to 100 days of casual employment on public works at the statutory minimum wage, contains special provisions to ensure full participation of women. In this paper, the status of women participation and their performance in MGNREGA in India, particularly in the state of West Bengal, has been discussed. The paper aims at equality of women in the provisions like priority of women participation in one third ratio of the total workers and ensuring equal wage rate in MGNREGA. The purpose of this paper is also to study, how women have empowered themselves with an innovative MGNREGA Program, particularly the women from socially and economically marginalized groups which ultimately leads to sustainable development of society as a whole. Even though globalization has changed every sphere of life, still issues like gender disparities, risk, vulnerability and challenges faced by women are prevalent in society. The active participation of women through woman empowerment will improve the GDP of the country and establish a new and developed economy.

Copy Right, IJAR, 2016. All rights reserved.

\section{Introduction:-}

The National Rural Employment Guarantee Act of 2005 (NREGA) was part of the commitments made by the United Progressive Alliance (UPA) government in its Common Minimum Program and came into force in February 2006. It has been hailed as a landmark and has attracted national and international attention.

It was notified that the MGNREGA is a scheme in post-independence period of our country which raised hopes in the minds of poor and unemployed people to earn something. It is one of the ambitious schemes launched by India with 200 rural districts in its first phase on $2^{\text {nd }}$ February 2006 which mandate to provide at least 100 days guaranteed wage employment to every rural household in a financial year. In FY 2007-08, it was extended to an additional 130 rural districts. The remaining districts were notified under MGNREGA with effect from 1 April 2008. Presently MGNREGA is working in the entire rural area of our country which covers 29 states, 6 union territories, 661 districts, 6,858 villages and 2, 62,260Gram Panchayats (GPs). At present scenario it has become the world's largest employment generation scheme. It is also worth mentioning that one of the major goals of MGNREGA is to target the weaker sections, including women. 
McKinsey's Research Report (Noshir and Anu, 2016) suggests that in India, women now contribute only 17 percent of country's GDP and make up just 24 percent of the workforce, compared with 40 percent globally. Public Workfare Program in India traditionally offered a unique opportunity for women to earn income in cash in a context where, too often, the ability of women to work outside the home is severely constrained by social norms. Three key features of the NREGA, later renamed in Oct. 2015 as Mahatma Gandhi National Rural Employment Guarantee Act (MGNREGA) set it apart from previous labor market interventions from the perspective of the opportunities it holds for women. First, the Act prescribes that at least one third of all workers be women. Second, the Act also provides for equal wages for men and women. This is especially significant in a context where women often receive a lower wage than men do even for similar tasks. Third, since the entitlement to at least100 days of work is at the household level, the allocation of the work within the household is left to the household members allowing space for the participation of women (Khera and Nayak, 2009). In addition to these three features, there are also provisions for facilities such as childcare at the worksites that aim to reduce the barriers to women's participation. In the context of opening bank accounts for wage payments, the recommendation is that the local government should consider individual and joint accounts to avoid crediting earnings solely to the male head of household.

\section{Women empowerment and MGNREGA:-}

Empowerment is a process aimed at changing the nature and direction of systematic forces, which marginalize women and other disadvantaged sections in a given context. Women comprise almost half of the population, so without their upliftment and progress, there cannot be true development in the world. Women empowerment is the empowerment of women which helps them to take their own decisions by breaking all personal limitations of the society and family. It is a multifaceted concept involving varied dimensions such as political, social, economic, legal and cultural, etc. It is also obvious that greater gender inequality undermines the process of economic development of the developing and the underdeveloped countries. The gender disparities prevailing in our rural society have been adversely affecting the quality of life of rural women. It is necessary to mobilize the vast women power, if the country has to progress in all sphere of development. Empowerment of women is a long and difficult process which has been emphasized since the ninth five year plan, should be promoted with full public support, and this could be successful only when those women living at the lower strata, who have been suppressed by the male dominated society taking undue advantage of their lack of education and poverty, can rise up to claim their rightful place in their own society. The national commission for women was set up by an Act of parliament in 1990 to safeguard the rights and legal entitlements of women. The $73^{\text {rd }}$ and $74^{\text {th }}$ Amendment (1993) to the constitution of India have provided for reservation of seats in the local bodies of Panchayats and municipalities for women, laying a strong foundation for their participation in decision making at the local level. The Government has framed different programs /schemes to uplift the women from poverty and vulnerability of life. One such women friendly program is Mahatma Gandhi National Rural Employment Guarantee Act. MGNREGA has provided a unique opportunity to people from rural India to earn their own income without any discrimination of caste or gender. Most remarkable feature of NREGA is that it pays women the same as men, something that was virtually unimaginable in rural India. However, some states have registered high percentage of women workers getting enrolled in the scheme whereas others have registered a very low percentage of women availing benefit under MGNREGA.

MGNREGA plays a significant role to meet the practical as well as strategic needs of women's participation. It has become a beacon of light in the empowerment of the rural women and contributed substantially for the increased living and economic conditions by creating equal wages to male and female workers. MGNREGA empowers women by giving them a scope of independent earning and spend some amount for their own needs. In rural areas, the dominance of males in intra-household decisions has been seen. MGNREGA has significant impact in converting some unpaid work into paid work and widen the scope of decision making role of women in household matters. Women's participation at the local and district level of governance process is low in spite of $73^{\text {rd }}$ Amendments of the Constitution. But women participation has increased after the implementation of MGNREGA in many areas. A large number of women workers attended the Gram Sabha meeting held in connection with MGNREGA. Community level empowerment of women is one of the greatest achievements of this Act.

\section{Literature Review:-}

Empirical studies are available on the role of MGNREGA through literature on which a unique attempt to provide a social safety net via a massive public works Program. 
Empowerment of women is closely linked to the opportunities they have in education, health, economic and political participation. In fact a large number of studies have shown that women have benefited under MGNREGA. Jogendera Sharma (2009) stated that in most of the districts in Rajasthan, Tamil Nadu and Andhra Pradesh supply exceeded demand whereas in case of Bihar there was no more supply than demand but the process of getting the job card is still rough around the edges with many of the states' unable to keep pace with the demand for the job cards and provision of the dated receipts. It has been also mentioned in his paper that the works were mostly related to water conservation in MGNREGA. Anupam Hazra (2009) indicated that as a result of implementation of MGNREGA, the wages raised, migration slowed down, productive assets created in rural India. He mentioned that the public awareness of the program is high in Rajasthan. Sanjay Roy (2009),based on the field survey in Tripura, indicated that creation of durable commodity assets like rural roads, water bodies, tanks, market sheds, for the unemployed youths have brought a shift in the livelihood of rural people and given a fresh impetus to the tottering hope of common people of Tripura. Gundati Ramesh and Krishna Kumar (2009) noticed that Andhra Pradesh is one of the successful states in implementing MGNREGA, especially empowering women. As per Subhabrata Dutta (2009) MGNREGA Program reduced the seasonal and disguised unemployment in the agricultural sector. MGNREGA eliminated contractors and middleman and played as a catalyst in rural economy. Sudha Narayanan and Upasak Das (2009) argued that states such as in Kerala, Himachal Pradesh, Sikkim, West Bengal, Meghalaya and Bihar, the women share in MGNREGA increases more than ten percent. They also stated that MGNREGA program is a demand driven program ought to provide employment to anyone who seeks work.

Richard Mahapatra (2010) indicated that with such huge number of works focusing on conserving and preserving water, NREGA would definitely impact agricultural productivity in the long run.

Sony Pellissery \& Sumit Kumar Jalan (2011)argued that currently MNREGA, the well-known public works program, has no impact on the social transformation (though legally claimed through provisions such as equal wages) that women involved in the program need, but we can nevertheless see huge potential for women to do more than benefit in terms of day-to-day welfare: the program has potential to support women's empowerment in the sense that it affords them the opportunity to experience their collective strength, and potentially redefine relations with men through involvement in the program. Srikantha Murthy and Indumati (2011) used macro level data on MGNREGA performance in drought-prone states of Karnataka and Rajasthan as well as in irrigation-dominated state of Andhra Pradesh. This study has revealed that the impact of MGNREGA wage on the economic scarcity of labour is relatively modest when compared with the impact of hike in non-farm wages. Even though the provision of food security through public distribution system has contributed to the economic scarcity of labour, the relative hike in non-farm wages is contributing to higher economic scarcity of labour rather than PDS and MGNREGA wages. The study has suggested subsidies for farm mechanization should be provided in order to sustain food and livelihood security in the drought-prone as well as irrigation-dominant states of India.

As per Jyoti Poonia (2012) women in Kerala who were not working previously have started to work on MGNREGA sites as the minimum wage under the MGNREGA is far greater than the agricultural wage. Surendra Singh (2013) indicated that Bundelkhand region of M.P. has a backward area and in this area MGNREGA had not provided 100 days job guarantee to who are willing to do jobs under this Scheme. Irregularities also found in implementation of MGNREGA in this area. Like Mustor roll was not prepared properly \& wages inequalities between women and men. But another picture is that it provided some amount of jobs for peoples in this area. In Bundelkhand region government data shows that jobs were provided under MGNREGA but social \& individual researches could not find them. In many cases found that jobs were provided to real beneficiaries and in some cases wages were not given after completion of work. Unemployment allowance which is another safe guard of this scheme not provided who wants jobs but unfortunately jobs were not provided within 15 days of jobs demanding.

Gangadhara Rao (2014) had made an attempt in the present paper to estimate the transformation in rural labour in terms of its composition and wages earned by it by analyzing field data collected from 10 villages from five districts located in the state of Andhra Pradesh.

Dinesha et. al. (2015) tried to understand how MGNREGA enables inclusive development. An attempt is made to analyze whether the program is really enabling Inclusive Economic Development using simple statistical tools. The study found that MGNREGA has made significant impact on the lives of backward communities and in the process making them a part of Economic Development. Gupta and Ahmad (2015) conducted a study in district Rajouri of 
J\&K state to examine the impact and durability of the assets created under MGNREGA. A few recommendations have also been made to further improve the quality of assets created under the program.

Shalini Nair (2016) argued that the number of persondays generated by women increased significantly but for few states like Maharashtra and Uttarakhand showed decreased level over the year.

All the above studies reveal that MGNREGA was implemented for growth and development of rural area by ensuring 100 days of employment. After a detailed study on this topic, it is clear that, most of the Panchayats as well as districts and states have taken initiative to implement this scheme. After going through the above studies, we have selected West Bengal as a case study because it has a lower rank $\left(14^{\text {th }}\right)$ in comparison to the other states in spite of having one of the largest populations $\left(4^{\text {th }}\right)$, where 68.11 percent population lives in rural area with agriculture dominating both the landscape and the economy. In this study, we would like to analyze the empowerment of women in West Bengal through MNREGA and its performance in comparison/with other states.

\section{Methodology:-}

Purpose of the Study:-

This study focuses on socio-economic development and women empowerment through MGNREGA. It analyses the implementation process throughout India and the impact of this act on economic empowerment of women in rural India, particularly in West Bengal. It also attempts to investigate the implementation of MGNREGA in West Bengal and it's achievement with emphasis on women participation rate, employment guarantee and strategies for further strengthening the Program.

\section{Research Objectives:-}

The following are the Research Objectives, based on the Purpose of the Study:

- To understand the participation of women in MGNREGA in India in general

- To examine the trend in participation of women in MGNREGA, particularly in West Bengal

- To analyze the trend of Total Individual workers with respect to Total Household workers in the nation as well as in West Bengal

- To study the influence of socio economic and demographic variables on woman participation rate in West Bengal

\section{Research Methodology:-}

To meet the objectives, secondary data has been collected from official Website of MGNREGA-Govt. of India. Also, information was captured from related articles published in Magazines, Journals, related books and official reports. The following tools were used during analysis:

- To analyze the trend in terms of persondays generated of women share with the help of percentages

- To view the trend of women participation rate at a glance, diagrams have been used

- We have made an Econometrics Analysis on woman participation rate, women population share, women literacy rate\& GDP growth rate to find significant relationship

- $\quad$ SPSS used for Data Analysis

\section{Data Analysis on Women Participation in MGNREGA:-}

Women empowerment was not the original intention of the MGNREGA, and was not its main objective. In a maledominant patriarchal society, it is very difficult to believe that women's decision to avail employment under the MGNREGA would get precedence over the decision of male family members. But from the very beginning it has played a remarkable role to meet the practical as well as strategic needs of women's participation. There are various factors which encourage the women workers participation under this scheme, such as, nature of work, limited hours of work, availability of work locally and substantial jump in the wage rate, etc. Today participation of women varies widely across India. 
Table 1:- MGNREGA at a glance: Recent Trends.

\begin{tabular}{|l|c|c|c|c|c|}
\hline \multicolumn{1}{|c|}{ Indicators } & FY 2012-13 & FY 2013-14 & FY 2014-15 & FY 2015-16 & $\begin{array}{c}\text { FY 2016-17 } \\
\text { (as on) }\end{array}$ \\
\hline Persondays Generated so far [in Cr.] & 230.46 & 220.37 & 166.21 & 235.5761 & 46.1983 \\
\hline Women Persondays out of Total (\%) & 51.3 & 52.82 & 54.88 & 55.21 & 56.05 \\
\hline Total Households Worked [in Cr.] & 4.99 & 4.79 & 4.14 & 4.8206 & 2.1932 \\
\hline Total Individuals Worked [in Cr.] & 7.97 & 7.39 & 6.22 & 7.2339 & 3.1221 \\
\hline \% of Men Worked & 52.93 & 52.03 & 49.77 & 49.7 & 45.16 \\
\hline \% of Women Worked & 47.07 & 47.97 & 50.23 & 50.3 & 54.84 \\
\hline Average Cost Per Day Per Person (in Rs.) & 170.34 & 183.47 & 206.13 & 208.03 & 196.52 \\
\hline
\end{tabular}

Source: http://mnregaweb4.nic.in/netnrega/all_lvl_details_dashboard_new.aspx.

Note: Here we have considered financial year till 2015-16 for the analysis part.

Nevertheless, women have availed of the paid employment opportunity under MGNREGA in large numbers. Women workers had a national average share of 51.3\% of total persondays generated in FY 2012-13, 52.82\% in FY 2013-14, 54.88\% in FY 2014-15, 55.21\% in FY 2015-16 and 56.05\% in FY 2016-17, exceeding expectations and has surpassed the statutory minimum share of $33 \%$ as shown in Table 1.

In terms of implementation it mandates that a minimum of one third of the beneficiaries are women who have registered and requested for work. However, the gender equality in participation in MGNREGA should be maintained. The act also provides equal wages for men and women and makes it possible for widows and other single women to access for work.

It is clear from Table 1, that women have generated 56.05\% of total persondays generated in FY 2016-17, which was 51.3\% in FY 2012-13. From here it can be stated that there is a $4.75 \%$ increase in women persondays generated in the last five years. It is also observed from Table 1 that the percentage of women workers participation has increased gradually from 47.07 in FY 2012-13 to 47.97 in FY 2013-14 to 50.23 in FY 2014-15 to 50.30 in FY 201516 to 54.84 in FY 2016-17, whereas the percentage of men workers participation has declined gradually from $52.93 \%$ in FY 2012-13 to 45.16\% in FY 2016-17.

Figure 1(a): Men \& Women participation trend in MGNREGA

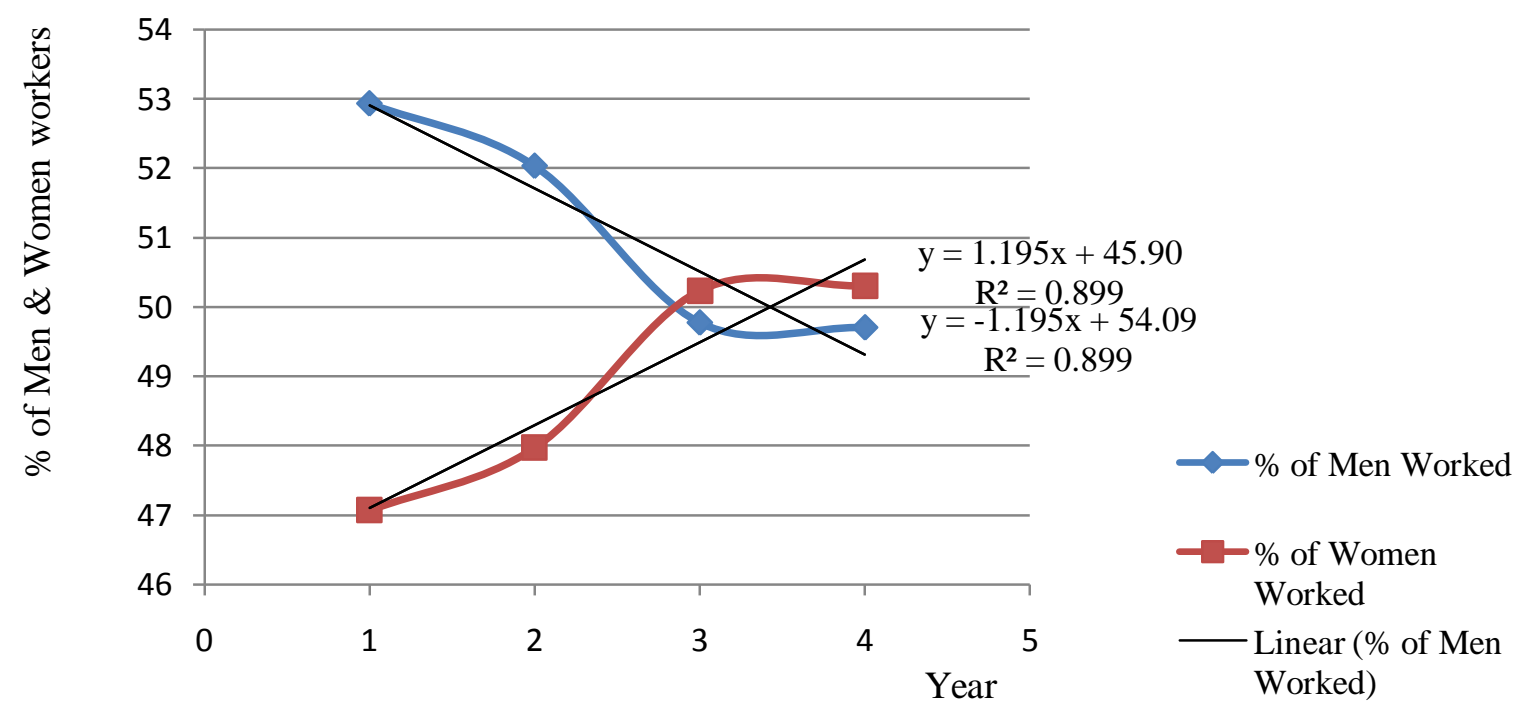

The above Figure 1(a) shows that there is an increasing trend of women participation rate in MGNREGA over the previous years. 
Figure 1(b): Trend of Total Individual workers with respect to Total Households workers

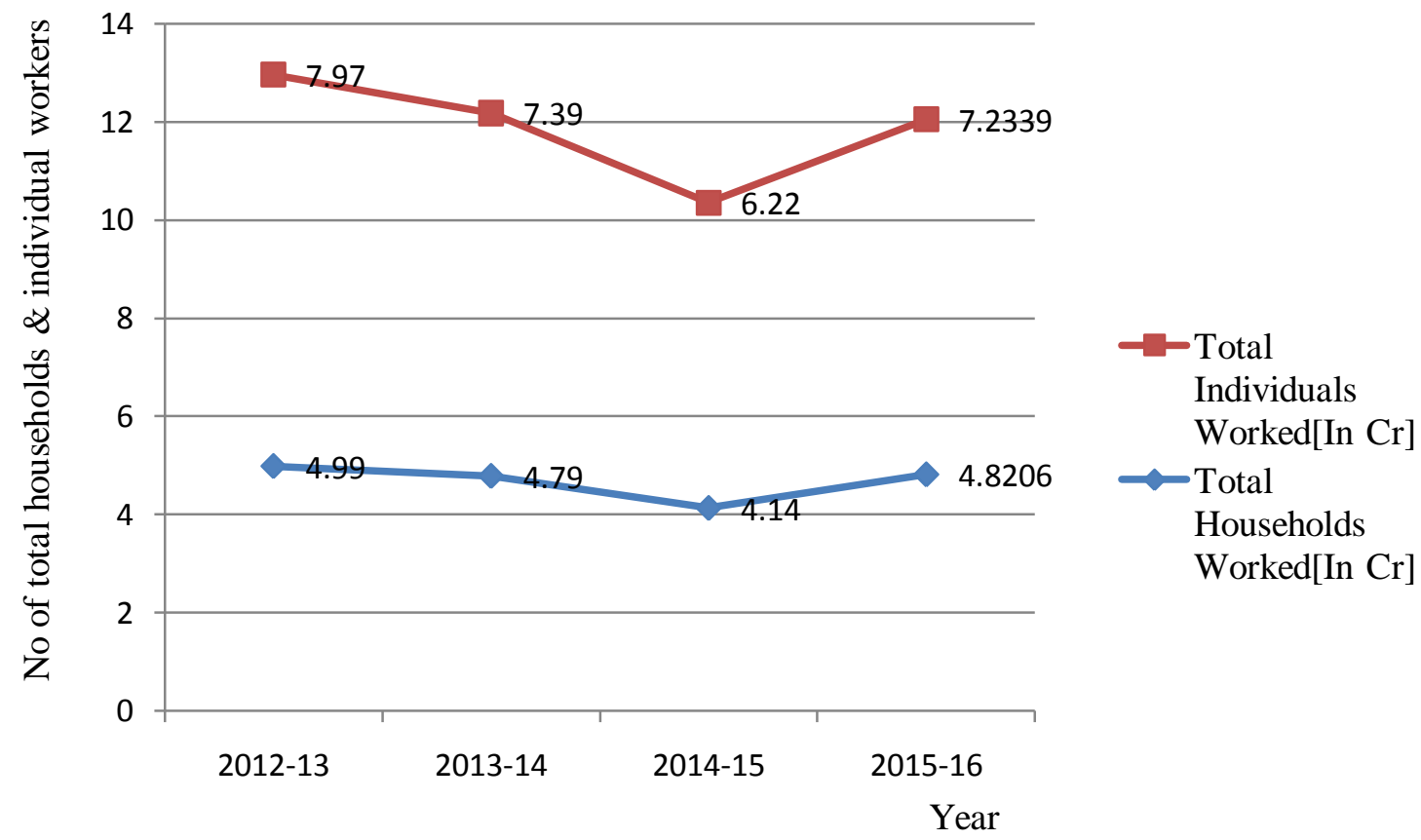

In figure 1(b) if we measure financial year on the horizontal axis and No of households \& individual workers on the vertical axis then we can find a proportional change rate between them.

Table 2(a):- Persondays Generated by Women in MGNREGA in India-state and Union Territory wise

\begin{tabular}{|c|c|c|c|c|c|c|c|c|c|c|c|}
\hline \multirow[t]{2}{*}{$\begin{array}{l}\mathrm{S} / \\
\mathrm{N}\end{array}$} & \multirow[t]{2}{*}{ State/UT } & \multicolumn{5}{|c|}{$\begin{array}{l}\text { No. of Women Persondays Generated (In } \\
\text { Lakh) }\end{array}$} & \multicolumn{5}{|c|}{$\begin{array}{l}\% \text { of Women Persondays Generated (In } \\
\text { Lakh) }\end{array}$} \\
\hline & & $\begin{array}{l}2012- \\
13\end{array}$ & $\begin{array}{l}2013- \\
14\end{array}$ & $\begin{array}{l}2014- \\
15\end{array}$ & $\begin{array}{l}2015- \\
16\end{array}$ & $\begin{array}{l}2016- \\
17 \text { (as on }\end{array}$ & $\begin{array}{l}2012- \\
13\end{array}$ & $\begin{array}{l}2013- \\
14\end{array}$ & $\begin{array}{l}2014- \\
15\end{array}$ & $\begin{array}{l}2015- \\
16\end{array}$ & $\begin{array}{l}2016- \\
17 \text { (as on) }\end{array}$ \\
\hline 1 & $\begin{array}{l}\text { ANDA } \\
\text { MAN } \\
\text { AND } \\
\text { NICOB } \\
\text { ER }\end{array}$ & 2.32 & 2.44 & 1.91 & 0.28 & 0 & 0.02 & 0.02 & 0.02 & 0.00 & 0.00 \\
\hline 2 & $\begin{array}{l}\text { ANDHRA } \\
\text { PRADESH }\end{array}$ & $\begin{array}{c}1113 . \\
23\end{array}$ & $\begin{array}{c}1056 . \\
13\end{array}$ & $\begin{array}{c}818.3 \\
8\end{array}$ & $\begin{array}{c}908.1 \\
8\end{array}$ & 219.16 & 10.49 & 9.70 & 9.98 & 9.22 & 19.95 \\
\hline 3 & $\begin{array}{l}\text { ARUNACH } \\
\text { AL } \\
\text { PRADESH }\end{array}$ & 7.54 & 10.57 & 2.66 & 13.35 & 0.15 & 0.07 & 0.10 & 0.03 & 0.14 & 0.01 \\
\hline 4 & ASSAM & 80.54 & 73.89 & 50.2 & $\begin{array}{c}118.3 \\
1\end{array}$ & 11.4 & 0.76 & 0.68 & 0.61 & 1.20 & 1.04 \\
\hline 5 & BIHAR & 251.8 & $\begin{array}{c}297.1 \\
1\end{array}$ & $\begin{array}{c}127.9 \\
6\end{array}$ & $\begin{array}{c}207.0 \\
7\end{array}$ & 26.52 & 2.37 & 2.73 & 1.56 & 2.10 & 2.41 \\
\hline 6 & $\begin{array}{l}\text { CHANDIGA } \\
\text { RH }\end{array}$ & 0 & 0 & 0 & 0 & 0 & 0.00 & 0.00 & 0.00 & 0.00 & 0.00 \\
\hline 7 & $\begin{array}{l}\text { CHHATTIS } \\
\text { GARH }\end{array}$ & $\begin{array}{c}555.1 \\
5\end{array}$ & $\begin{array}{c}629.4 \\
2\end{array}$ & $\begin{array}{c}276.4 \\
3\end{array}$ & $\begin{array}{c}335.7 \\
5\end{array}$ & 47.5 & 5.23 & 5.78 & 3.37 & 3.41 & 4.32 \\
\hline
\end{tabular}




\begin{tabular}{|c|c|c|c|c|c|c|c|c|c|c|c|}
\hline 8 & $\begin{array}{ll}\text { DADRA } & \& \\
\text { NAGAR } & \\
\text { HAVELI } & \end{array}$ & 0 & 0 & 0 & 0 & 0 & 0.00 & 0.00 & 0.00 & 0.00 & 0.00 \\
\hline 9 & $\begin{array}{l}\text { DAMAN \& } \\
\text { DIU }\end{array}$ & 0 & 0 & 0 & 0 & 0 & 0.00 & 0.00 & 0.00 & 0.00 & 0.00 \\
\hline 10 & GOA & 0.45 & 0.87 & 1.15 & 0.67 & 0.02 & 0.00 & 0.01 & 0.01 & 0.01 & 0.00 \\
\hline 11 & GUJARAT & $\begin{array}{c}119.8 \\
7\end{array}$ & $\begin{array}{c}101.2 \\
5\end{array}$ & 74.08 & 68.05 & 12.29 & 1.13 & 0.93 & 0.90 & 0.69 & 1.12 \\
\hline 12 & HARYANA & 50.54 & 49.06 & 23.62 & 18.3 & 1.11 & 0.48 & 0.45 & 0.29 & 0.19 & 0.10 \\
\hline 13 & $\begin{array}{l}\text { HIMACHAL } \\
\text { PRADESH }\end{array}$ & $\begin{array}{c}145.1 \\
4\end{array}$ & $\begin{array}{c}176.3 \\
6 \\
\end{array}$ & $\begin{array}{c}105.7 \\
3 \\
\end{array}$ & 97.58 & 4.96 & 1.37 & 1.62 & 1.29 & 0.99 & 0.45 \\
\hline 14 & $\begin{array}{l}\text { JAMMU } \\
\text { AND } \\
\text { KASHMIR }\end{array}$ & 49.37 & 76.38 & 18.74 & 37.46 & 0.5 & 0.47 & 0.70 & 0.23 & 0.38 & 0.05 \\
\hline 15 & $\begin{array}{l}\text { JHARKHAN } \\
\text { D }\end{array}$ & $\begin{array}{c}179.7 \\
9\end{array}$ & $\begin{array}{c}139.1 \\
1\end{array}$ & $\begin{array}{c}132.6 \\
5\end{array}$ & 150.6 & 36.55 & 1.69 & 1.28 & 1.62 & 1.53 & 3.33 \\
\hline 16 & $\begin{array}{l}\text { KARNATA } \\
\text { KA }\end{array}$ & $\begin{array}{c}287.6 \\
2\end{array}$ & $\begin{array}{c}334.7 \\
1\end{array}$ & $\begin{array}{c}188.8 \\
1\end{array}$ & $\begin{array}{c}184.5 \\
6\end{array}$ & 30.31 & 2.71 & 3.07 & 2.30 & 1.87 & 2.76 \\
\hline 17 & KERALA & $\begin{array}{c}777.8 \\
4\end{array}$ & $\begin{array}{c}808.5 \\
2\end{array}$ & $\begin{array}{c}459.3 \\
3\end{array}$ & $\begin{array}{c}552.1 \\
9\end{array}$ & 5.79 & 7.33 & 7.43 & 5.60 & 5.60 & 0.53 \\
\hline 18 & $\begin{array}{l}\text { LAKSHAD } \\
\text { WEEP }\end{array}$ & 0.14 & 0.03 & 0.03 & 0.01 & 0 & 0.00 & 0.00 & 0.00 & 0.00 & 0.00 \\
\hline 19 & $\begin{array}{l}\text { MADHYA } \\
\text { PRADESH }\end{array}$ & $\begin{array}{c}472.2 \\
2\end{array}$ & $\begin{array}{c}521.6 \\
4\end{array}$ & $\begin{array}{c}497.0 \\
1\end{array}$ & $\begin{array}{c}451.2 \\
9\end{array}$ & 35.45 & 4.45 & 4.79 & 6.06 & 4.58 & 3.23 \\
\hline 20 & $\begin{array}{l}\text { MAHARAS } \\
\text { HTRA }\end{array}$ & $\begin{array}{c}362.7 \\
7 \\
\end{array}$ & $\begin{array}{c}224.5 \\
2 \\
\end{array}$ & $\begin{array}{c}236.6 \\
7\end{array}$ & $\begin{array}{c}239.2 \\
4\end{array}$ & 46.74 & 3.42 & 2.06 & 2.89 & 2.43 & 4.26 \\
\hline 21 & MANIPUR & 57.46 & 39.81 & 34.82 & 18.89 & 2.22 & 0.54 & 0.37 & 0.42 & 0.19 & 0.20 \\
\hline 22 & $\begin{array}{l}\text { MEGHALA } \\
\text { YA }\end{array}$ & 56.37 & 85.67 & 51.94 & 50.23 & 0 & 0.53 & 0.79 & 0.63 & 0.51 & 0.00 \\
\hline 23 & MIZORAM & 29.97 & 37.34 & 14.55 & 32.52 & 7.29 & 0.28 & 0.34 & 0.18 & 0.33 & 0.66 \\
\hline 24 & $\begin{array}{l}\text { NAGALAN } \\
\text { D }\end{array}$ & 33.19 & 49.83 & 20.57 & 53.15 & 5.3 & 0.31 & 0.46 & 0.25 & 0.54 & 0.48 \\
\hline 25 & ODISHA & $\begin{array}{c}196.0 \\
5\end{array}$ & $\begin{array}{c}238.7 \\
5\end{array}$ & 157.7 & $\begin{array}{c}234.4 \\
9\end{array}$ & 29.45 & 1.85 & 2.19 & 1.92 & 2.38 & 2.68 \\
\hline 26 & $\begin{array}{l}\text { PUDUCHER } \\
\text { RY }\end{array}$ & 7.29 & 7.24 & 2.46 & 4.29 & 0 & 0.07 & 0.07 & 0.03 & 0.04 & 0.00 \\
\hline 27 & PUNJAB & 29.68 & 70.96 & 33.24 & 62.78 & 4.84 & 0.28 & 0.65 & 0.41 & 0.64 & 0.44 \\
\hline 28 & $\begin{array}{l}\text { RAJASTHA } \\
\mathrm{N}\end{array}$ & $\begin{array}{c}1504 . \\
45\end{array}$ & $\begin{array}{c}1245 . \\
55\end{array}$ & $\begin{array}{c}1079 . \\
48\end{array}$ & $\begin{array}{c}1294 . \\
86\end{array}$ & 163.31 & 14.18 & 11.44 & 13.17 & 13.14 & 14.87 \\
\hline 29 & SIKKIM & 14.8 & 19.44 & 9.52 & 14.65 & 1.25 & 0.14 & 0.18 & 0.12 & 0.15 & 0.11 \\
\hline 30 & $\begin{array}{l}\text { TAMIL } \\
\text { NADU }\end{array}$ & $\begin{array}{c}3025 . \\
62\end{array}$ & $\begin{array}{c}3072 . \\
03\end{array}$ & $\begin{array}{c}2045 . \\
62\end{array}$ & $\begin{array}{c}2406 . \\
68\end{array}$ & 218.6 & 28.51 & 28.22 & 24.95 & 24.42 & 19.90 \\
\hline 31 & $\begin{array}{l}\text { TELANGAN } \\
\text { A }\end{array}$ & 0 & 0 & 578.2 & $\begin{array}{c}648.9 \\
6 \\
\end{array}$ & 138.26 & 0.00 & 0.00 & 7.05 & 6.59 & 12.59 \\
\hline 32 & TRIPURA & $\begin{array}{c}212.6 \\
8\end{array}$ & $\begin{array}{c}247.6 \\
7\end{array}$ & $\begin{array}{c}222.0 \\
7\end{array}$ & 253.6 & 5.24 & 2.00 & 2.28 & 2.71 & 2.57 & 0.48 \\
\hline 33 & $\begin{array}{l}\text { UTTAR } \\
\text { PRADESH }\end{array}$ & 270.7 & $\begin{array}{c}385.1 \\
9\end{array}$ & $\begin{array}{c}270.9 \\
8\end{array}$ & $\begin{array}{c}373.5 \\
8\end{array}$ & 27.28 & 2.55 & 3.54 & 3.31 & 3.79 & 2.48 \\
\hline 34 & $\begin{array}{l}\text { UTTARAK } \\
\text { HAND }\end{array}$ & 73.84 & 71.91 & 56.24 & 74.1 & 6.32 & 0.70 & 0.66 & 0.69 & 0.75 & 0.00 \\
\hline 35 & $\begin{array}{l}\text { WEST } \\
\text { BENGAL }\end{array}$ & $\begin{array}{c}644.3 \\
2\end{array}$ & $\begin{array}{c}812.7 \\
6\end{array}$ & $\begin{array}{c}605.1 \\
8\end{array}$ & $\begin{array}{c}948.6 \\
4\end{array}$ & 10.63 & 6.07 & 7.47 & 7.38 & 9.63 & 0.97 \\
\hline & Grand Total & $\begin{array}{c}1061 \\
2.8\end{array}$ & $\begin{array}{c}1088 \\
6.2\end{array}$ & $\begin{array}{c}8197 . \\
93\end{array}$ & $\begin{array}{c}9854 . \\
31\end{array}$ & 1098.44 & 100 & 100 & 100 & 100 & 100 \\
\hline
\end{tabular}


Source: http://164.100.129.6/Netnrega/mpr_ht/nregampr_dmu_mis.aspx?fin_year=2015 2016\&month=Latest\&flag $=1 \&$ page $1=S$

Note: Here we have considered financial year till 2015-16 for the analysis part.

Table 2(a) shows the total no of persondays generated by women in all the states \& union territories of India and their respective ratio throughout the country. It is clear from the table that in FY 2016-17 Andhra Pradesh is the leading state in the country to generate highest number of persondays i.e., $19.95 \%$ followed by Tamil Nadu (19.90\%), Rajasthan (14.87\%), Telangana (12.58\%) and Chhattisgarh (4.32\%). It is clear from the above table that Tamil Nadu was the leading state among all states and union territories for the last four previous years $(24.42 \%$ in FY 2015-16, 24.95\% in FY 2014-15, 28.21\% in FY 2014-15, 28.21\% in FY 2013-14 and 28.50\% in FY 2012-13). It is also noticeable that the states like Rajasthan \& Telangana have shown that the percentage of women persondays generated have increased significantly and has secured $3^{\text {rd }}(14.86 \%)$ and $4^{\text {th }}(12.58 \%)$ rank respectively in the present FY 2016-17. Again in the case of West Bengal an increasing trend was found in women persondays generated till FY 2015-16.

Table 2(a) also reflects that union territories like Dadra \& Nagar Haveli, Daman \& Diu and Chandigarh have not shown any women participation and very less participation exist in Andaman \&Nicobar, Lakshadweep and Puducherry in MGNREGA for the last five years because these union territories have either not demanded any employment or even if demanded, the ratio is very less which has been shown in Table 2(b).

Table 2(b):- No of Households who have demanded employment in UTs.

\begin{tabular}{|l|l|c|c|c|c|c|}
\hline S/N & Union Territory & \multicolumn{5}{|c|}{ No of Households who have demanded employment } \\
\hline & & $2012-13$ & $2013-14$ & $2014-15$ & $2015-16$ & $2016-17$ \\
\hline 1 & Andaman \& Nicobar & 15496 & 12652 & 11828 & 2697 & 0 \\
\hline 2 & Chandigarh & 0 & 0 & 0 & 0 & 0 \\
\hline 3 & Dadra \& Nagar Haveli & 0 & 0 & 0 & 0 & 0 \\
\hline 4 & Daman \& Diu & 0 & 0 & 0 & 0 & 0 \\
\hline 5 & Lakshadweep & 1963 & 926 & 539 & 138 & 3 \\
\hline 6 & Puducherry & 41443 & 43807 & 35512 & 37303 & 0 \\
\hline
\end{tabular}

Source:-http://164.100.129.6/Netnrega/mpr_ht/nregampr_dmu_mis.aspx?fin_year=20152016\&month=Latest\&flag=1\&page $1=\mathrm{S}$

West Bengal- Women Participation in MGNREGA and the Changing Scenario:-

West Bengal is situated in eastern India, between the Himalayas and the Bay of Bengal. Kolkata is the capital of this state, previously it was known as Calcutta, retains architectural and cultural remnants of its past as an East India Company trading post and the capital of the British Raj. The area of West Bengal is $88,752 \mathrm{~km}^{2}$, with population of around 9.13 crores where $68 \%$ of its population resides in rural area as per census 2011. The state consists of 20 districts, 341 blocks and 3,347 Gram Panchayats (GPs). Agriculture plays a pivotal role in the State's economy and nearly three out of every four persons are directly or indirectly involved in agriculture. Agriculture is the main source of income for the people of West Bengal. About $70 \%$ of the total population depends on farming for their livelihood. The state has 3\% cultivable land which accounts for $8 \%$ of the total food grains produced in the nation.

In West Bengal MGNREGA was introduced in ten districts in the first phase, in seven districts in the second phase and in rest of the districts in the third phase. A detail explanation of the trend of women participation in MGNREGA in West Bengal has been discussed below with the help of Table 3.

Table 3:- West Bengal at a Glance in MGNREGA.

\begin{tabular}{|l|l|}
\hline Total No. of Districts & 20 \\
\hline Total No. of Blocks & 341 \\
\hline Total No. of GPs & 3,347 \\
\hline Districts under Phase I & $\begin{array}{l}10(24 \text { Parganas South, Bankura, Birbhum, Dinajpur Dakshin, Dinajpur Uttar, } \\
\text { Jalpaiguri, Maldah, Purba Medinipur, Murshidabad, Purulia) }\end{array}$ \\
\hline Districts under Phase II & $\begin{array}{l}7 \text { (Cooch Behar, Nadia, Burdwan, Paschim Medinipur, 24 Parganas North, Hooghly, } \\
\text { Darjeeling Gorkha Hill Council (DGHC) })\end{array}$ \\
\hline
\end{tabular}




\begin{tabular}{|c|c|c|c|c|c|}
\hline Districts under Phase III & \multicolumn{5}{|c|}{3 (Siliguri Mahakuma Parisad, Howrah, Alipurduar) } \\
\hline Indicators & FY 2012-13 & FY 2013-14 & FY 2014-15 & FY 2015-16 & $\begin{array}{l}\text { FY 2016-17 } \\
\text { (as on) }\end{array}$ \\
\hline $\begin{array}{l}\text { Persondays Generated so far[In } \\
\text { Lakhs] }\end{array}$ & 2018.42 & 2296.34 & 1696.29 & 2866.12 & 92.44 \\
\hline $\begin{array}{l}\text { Women Persondays out of Total } \\
(\%)\end{array}$ & 33.71 & 35.7 & 41.4 & 46.27 & 45.11 \\
\hline $\begin{array}{l}\text { Total Households Worked[In } \\
\text { Lakhs] }\end{array}$ & 58.17 & 61.33 & 51.19 & 61.12 & 6.03 \\
\hline $\begin{array}{l}\text { Total Individuals Worked[In } \\
\text { Lakhs] }\end{array}$ & 88.01 & 91.69 & 73.53 & 91.6 & 7.94 \\
\hline$\%$ of Men Worked & 64.98 & 63.67 & 60.56 & 56.3 & 55.62 \\
\hline$\%$ of Women Worked & 35.02 & 36.33 & 39.44 & 43.7 & 44.38 \\
\hline
\end{tabular}

Source:http://mnregaweb4.nic.in/netnrega/all_lvl_details_dashboard_new.aspx Note: Here we have considered financial year till 2015-16 for the analysis part.

Table 3 shows that in West Bengal, women have generated 45.11\% persondays in FY 2016-17, which was 33.71\% in the FY 2012-13. After observing the previous five years data, it can be stated that the participation of women in MGNREGA in West Bengal seems to be increasing over the previous years. Again Table 3 and Figure 3(a) show that the percentage of women participation of in MGNREGA in West Bengal is maintaining an increasing trend whereas it is decreasing in the case of men. So it can be stated that women have participated significantly and have shown their interest to participate under MGNREGA.

Figure 3(a): Trend of Men \& Women participation in MGNREGA in West Bengal

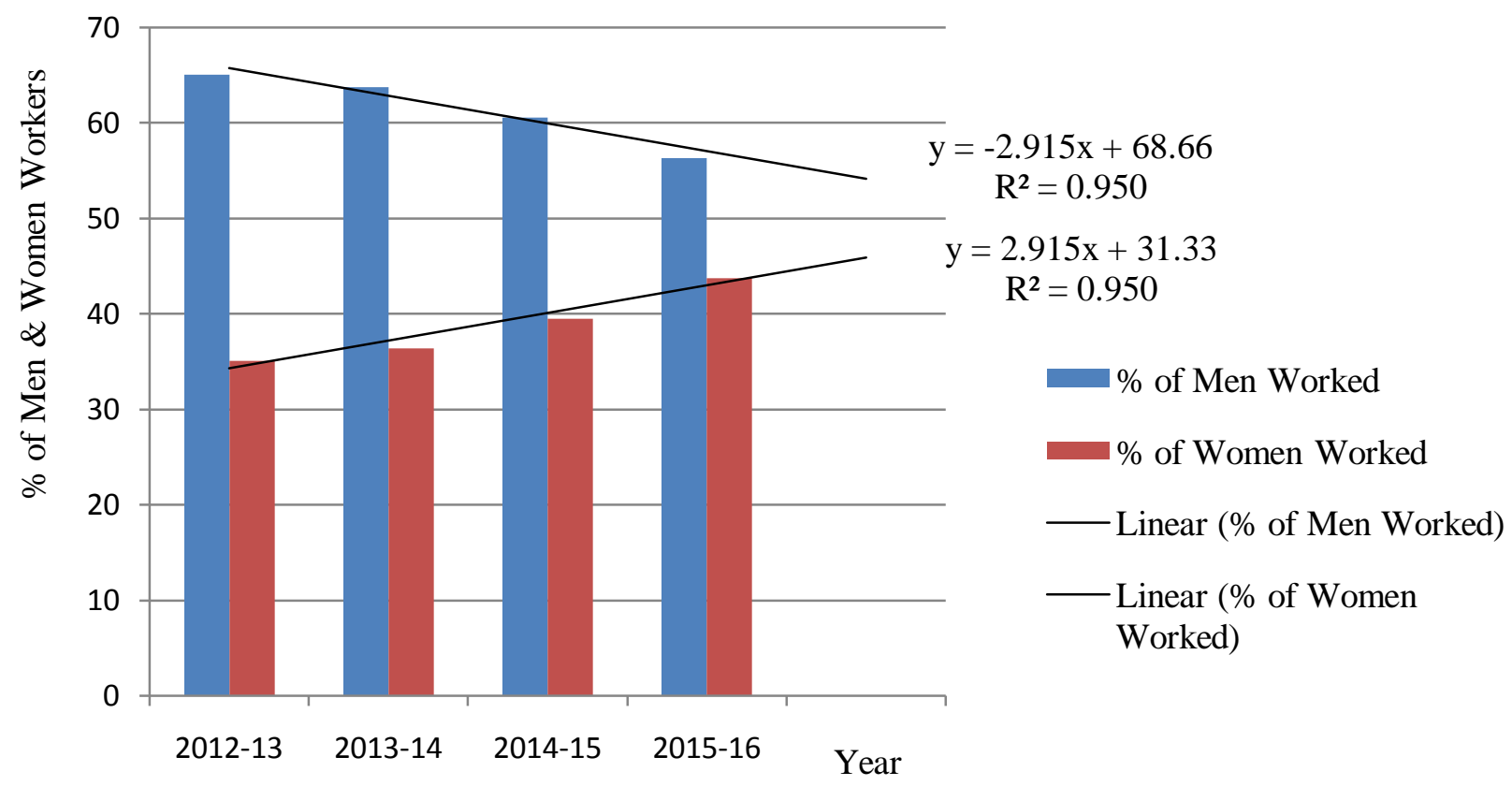


In the following figure 3(b) we can find a proportional change rate between the Total Household workers and Total Individual workers with an increasing trend.

Figure 3(b): Trend of Total Individual workers with respect to Total Household workers in West Bengal

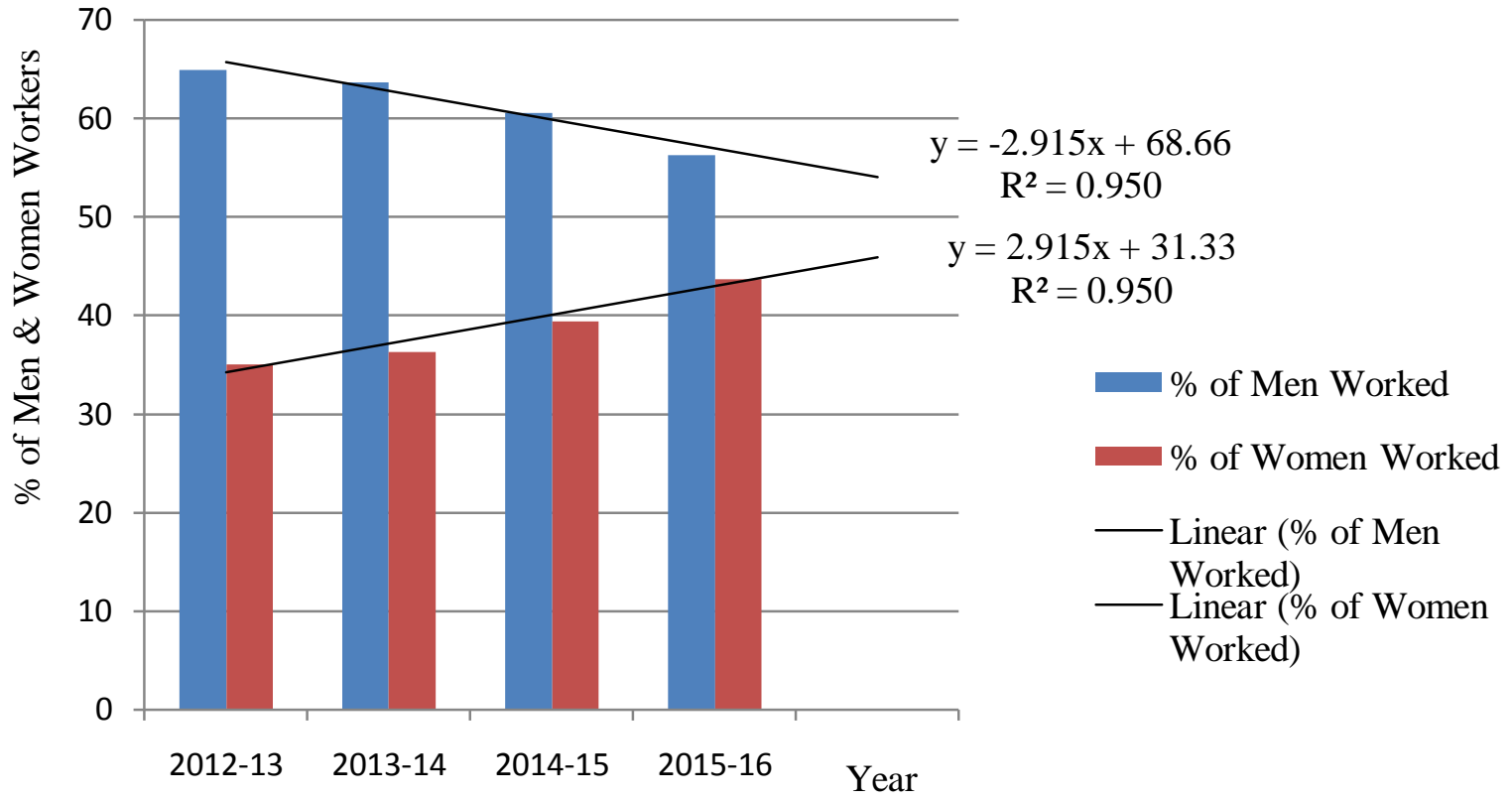

Table 4:- Persondays Generated by Women in MGNREGA in West Bengal-district wise.

\begin{tabular}{|c|c|c|c|c|c|c|c|c|c|c|c|}
\hline $\begin{array}{l}\mathbf{S} / \\
\mathbf{N}\end{array}$ & District & \multicolumn{5}{|c|}{$\begin{array}{c}\text { No. of Women Persondays Generated (In } \\
\text { Lakh) }\end{array}$} & \multicolumn{5}{|c|}{$\begin{array}{c}\% \text { of Women Persondays Generated (In } \\
\text { Lakh) }\end{array}$} \\
\hline & & $\begin{array}{l}2012- \\
13\end{array}$ & $\begin{array}{l}2013- \\
14\end{array}$ & $\begin{array}{l}2014- \\
15\end{array}$ & $\begin{array}{l}2015- \\
16\end{array}$ & $\begin{array}{l}2016- \\
17 \text { (as } \\
0 \text { n) }\end{array}$ & $\begin{array}{l}2012- \\
13\end{array}$ & $\begin{array}{l}2013- \\
14\end{array}$ & $\begin{array}{l}2014- \\
15\end{array}$ & $\begin{array}{l}2015- \\
16\end{array}$ & $\begin{array}{l}2016- \\
17 \text { (as } \\
\text { on) }\end{array}$ \\
\hline 1 & $\begin{array}{l}\text { 24 PARGANAS } \\
\text { (NORTH) }\end{array}$ & 50.92 & 29.76 & 26.77 & 36.93 & 0.57 & 7.90 & 3.66 & 4.42 & 3.89 & 5.36 \\
\hline 2 & $\begin{array}{l}\text { 24 PARGANAS } \\
\text { SOUTH }\end{array}$ & 26.98 & 31.37 & 24.95 & 73.05 & 0.63 & 4.19 & 3.86 & 4.12 & 7.70 & 5.93 \\
\hline 3 & ALIPURDUAR & 0 & 0 & 0 & 27.22 & 0 & 0.00 & 0.00 & 0.00 & 2.87 & 0.00 \\
\hline 4 & BANKURA & 54.04 & 48.82 & 17.22 & 46.22 & 0.51 & 8.39 & 6.01 & 2.85 & 4.87 & 4.80 \\
\hline 5 & BIRBHUM & 51.21 & 61.87 & 32.5 & 85.21 & 0.31 & 7.95 & 7.61 & 5.37 & 8.98 & 2.92 \\
\hline 6 & BURDWAN & 66.9 & 90.92 & 99.57 & 93.8 & 2.23 & 10.38 & 11.19 & 16.45 & 9.89 & 20.98 \\
\hline 7 & COOCHBEHAR & 9.76 & 38.36 & 49.17 & $\begin{array}{c}116.8 \\
7\end{array}$ & 0.41 & 1.51 & 4.72 & 8.12 & 12.32 & 3.86 \\
\hline 8 & $\begin{array}{l}\text { Darjeeling Gorkha } \\
\text { Hill Council (DGHC) }\end{array}$ & 28.88 & 25.96 & 17.7 & 18.41 & 0 & 4.48 & 3.19 & 2.92 & 1.94 & 0.00 \\
\hline 9 & $\begin{array}{l}\text { DINAJPUR } \\
\text { DAKSHIN }\end{array}$ & 6.7 & 5.45 & 3.06 & 8.36 & 0 & 1.04 & 0.67 & 0.51 & 0.88 & 0.00 \\
\hline 10 & DINAJPUR UTTAR & 5.23 & 5.35 & 4.81 & 17.78 & 0.26 & 0.81 & 0.66 & 0.79 & 1.87 & 2.45 \\
\hline 11 & HOOGHLY & 61.71 & 86.8 & 39.26 & 77.84 & 1.76 & 9.58 & 10.68 & 6.49 & 8.21 & 16.56 \\
\hline
\end{tabular}




\begin{tabular}{|c|l|c|c|c|c|c|c|c|c|c|c|c|}
\hline 12 & HOWRAH & 7.69 & 6.24 & 8.23 & 11.67 & 0 & 1.19 & 0.77 & 1.36 & 1.23 & 0.00 \\
\hline 13 & JALPAIGURI & 42.71 & 51.91 & 29.27 & 23.45 & 0 & 6.63 & 6.39 & 4.84 & 2.47 & 0.00 \\
\hline 14 & MALDAH & 15.64 & 22.48 & 11.42 & 23.24 & 0.21 & 2.43 & 2.77 & 1.89 & 2.45 & 1.98 \\
\hline 15 & MURSHIDABAD & 17.02 & 26.15 & 19.25 & 18.05 & 0.08 & 2.64 & 3.22 & 3.18 & 1.90 & 0.75 \\
\hline 16 & NADIA & 31.95 & 62.15 & 76.16 & 88.96 & 0.07 & & 4.96 & 7.65 & 12.58 & 9.38 & 0.66 \\
\hline 17 & $\begin{array}{l}\text { PASCHIM } \\
\text { MEDINIPUR }\end{array}$ & 54.23 & 78.77 & 69.29 & 88.99 & 1.73 & 8.42 & 9.69 & 11.45 & 9.38 & 16.27 \\
\hline 18 & $\begin{array}{l}\text { PURBA } \\
\text { MEDINIPUR }\end{array}$ & 72.98 & 88.17 & 54.86 & 60.23 & 1.56 & 11.33 & 10.85 & 9.07 & 6.35 & 14.68 \\
\hline 19 & PURULIA & 34.74 & 42.45 & 16.16 & 25.86 & 0.24 & 5.39 & 5.22 & 2.67 & 2.73 & 2.26 \\
\hline 20 & $\begin{array}{l}\text { SILIGURI } \\
\text { MAHAKUMA } \\
\text { PARISAD }\end{array}$ & 5.03 & 9.78 & 5.53 & 6.5 & 0.06 & 0.78 & 1.20 & 0.91 & 0.69 & 0.56 \\
\hline & Grand Total & 644.3 & 812.7 & 605.1 & 948.6 & 10.63 & 100 & 100 & 100 & 100 & 100 \\
\hline
\end{tabular}

Source:http://164.100.129.6/Netnrega/mpr_ht/nregampr_dmu.aspx?state_code=32\&flag=11\&page1=D\&mon th=Latest\&fin_year=2010-2011

Table 4 shows the total no of persondays generated by women in all the districts of West Bengal and their respective ratio throughout the State. It is clear from the above table that in FY 2016-17 Burdwan is the leading district in the state to generate highest number of persondays i.e., 20.98\% in FY 2015-16 Coochbehar was in the leading position with 12.32\% persondays, in FY 2014-15 \& FY 2013-14 again Burdwan was the leading district and in FY 2012-13 Purba Medinipur was in the leading position with $11.33 \%$ persondays. On the basis of above data we can get a mixed result regarding the performance of MGNREGA in the districts of West Bengal. Some districts like Burdwan, Coochbehar and Paschim Medinipur are maintaining an increasing trend to some extent but the performance of districts like Alipurduar, Siliguri Mahakuma Parisad and Uttar Dinajpur are very bad. Rest of the districts are maintaining both the increasing and decreasing trend.

Table 5(a): -Demographic and GDP data analysis.

\begin{tabular}{|l|l|l|l|c|c|}
\hline S/N & District & $\begin{array}{l}\text { Women } \\
\text { Participation Rate } \\
(\%)\end{array}$ & $\begin{array}{l}\text { Female } \\
\text { Literacy Rate } \\
(\%)\end{array}$ & $\begin{array}{l}\text { Female } \\
\text { Population share } \\
(\%)\end{array}$ & $\begin{array}{l}\text { GDP Growth } \\
\text { Rate } \%\end{array}$ \\
\hline 1 & 24-Parganas (North) & 26.27 & 81.05 & 46.47 & 18.69 \\
\hline 2 & 24-Parganas (South) & 15.38 & 72.09 & 44.67 & 19.47 \\
\hline 3 & Bankura & 37.99 & 60.44 & 41.62 & 7.12 \\
\hline 4 & Birbhum & 31.17 & 64.07 & 44.17 & 14.69 \\
\hline 5 & Burdwan & 45.06 & 70.47 & 44.32 & 15.47 \\
\hline 6 & Cooch Behar & 23.93 & 69.08 & 44.37 & 12.98 \\
\hline 7 & Dakshin Dinajpur & 31.56 & 67.81 & 44.85 & 20.33 \\
\hline 8 & Darjeeling & 42.31 & 73.74 & 45.51 & 17.61 \\
\hline 9 & Hooghly & 34.02 & 76.95 & 45.64 & 18.54 \\
\hline 10 & Howrah & 19.01 & 79.73 & 45.85 & 18.61 \\
\hline 11 & Jalpaiguri & 44.99 & 66.65 & 44.12 & 17.85 \\
\hline 12 & Malda & 30.41 & 57.84 & 44.65 & 18.93 \\
\hline 13 & Midnapore East & 44.58 & 81.81 & 45.12 & 19.04 \\
\hline 14 & Midnapore West & 30.43 & 71.11 & 44.08 & 14.91 \\
\hline 15 & Murshidabad & 13.23 & 63.88 & 46.23 & 19.37 \\
\hline 16 & Nadia & 31.05 & 71.35 & 45.89 & 17.22 \\
\hline 17 & Purulia & 38.93 & 51.29 & 38.35 & 8.17 \\
\hline 18 & Uttar Dinajpur & 33.62 & 53.15 & 42.68 & 21.02 \\
\hline
\end{tabular}

Source: 1. Census 2011, 2.http://164.100.129.6/Netnrega/mpr_ht/nregampr_dmu.aspx?state_code=32\&flag=11\&page1=D\&month=La test\&fin _year $=2010-2011$ 
In the above Table 5(a), we have accumulated some demographical data on female, district wise GDP growth rate from the last census, 2011 and women participation rate of the financial year 2010-11 for analyzing the relationship between them. Here we have considered only 18 districts because there were only 18 districts at the time of census 2011.

Table 5(b):- Correlation Analysis.

\begin{tabular}{|c|c|c|c|c|c|}
\hline \multicolumn{6}{|c|}{ Correlations } \\
\hline & & $\begin{array}{c}\text { Women } \\
\text { Participation } \\
\text { Rate (\%) }\end{array}$ & $\begin{array}{c}\text { Female } \\
\text { Literacy Rate } \\
(\%)\end{array}$ & $\begin{array}{c}\text { Female } \\
\text { Population } \\
\text { share }(\%)\end{array}$ & $\begin{array}{l}\text { GDP Growth } \\
\text { Rate } \%\end{array}$ \\
\hline \multirow{3}{*}{$\begin{array}{l}\text { Women Participation Rate } \\
(\%)\end{array}$} & Pearson Correlation & 1 & -.091 & -.358 & -.268 \\
\hline & Sig. (1-tailed) & & .360 & .072 & .141 \\
\hline & $\mathrm{N}$ & 18 & 18 & 18 & 18 \\
\hline \multirow[t]{3}{*}{ Female Literacy Rate (\%) } & Pearson Correlation & -.091 & 1 & $.739^{* *}$ & .384 \\
\hline & Sig. (1-tailed) & .360 & & .000 & .058 \\
\hline & $\mathrm{N}$ & 18 & 18 & 18 & 18 \\
\hline \multirow{3}{*}{$\begin{array}{l}\text { Female Population share } \\
(\%)\end{array}$} & Pearson Correlation & -.358 & $.739^{* *}$ & 1 & $.723^{* *}$ \\
\hline & Sig. (1-tailed) & .072 & .000 & & .000 \\
\hline & $\mathrm{N}$ & 18 & 18 & 18 & 18 \\
\hline \multirow[t]{3}{*}{ GDP Growth Rate \% } & Pearson Correlation & -.268 & .384 & $.723^{* *}$ & 1 \\
\hline & Sig. (1-tailed) & .141 & .058 & .000 & \\
\hline & $\mathrm{N}$ & 18 & 18 & 18 & 18 \\
\hline
\end{tabular}

From the above table it is clear that female population share is highly (positive) correlated with female literacy rate and GDP growth rate. So from the analysis it can be said that if female population share will increase i.e., gender equality will be more, then women participation rate will be more and it will generate more GDP.

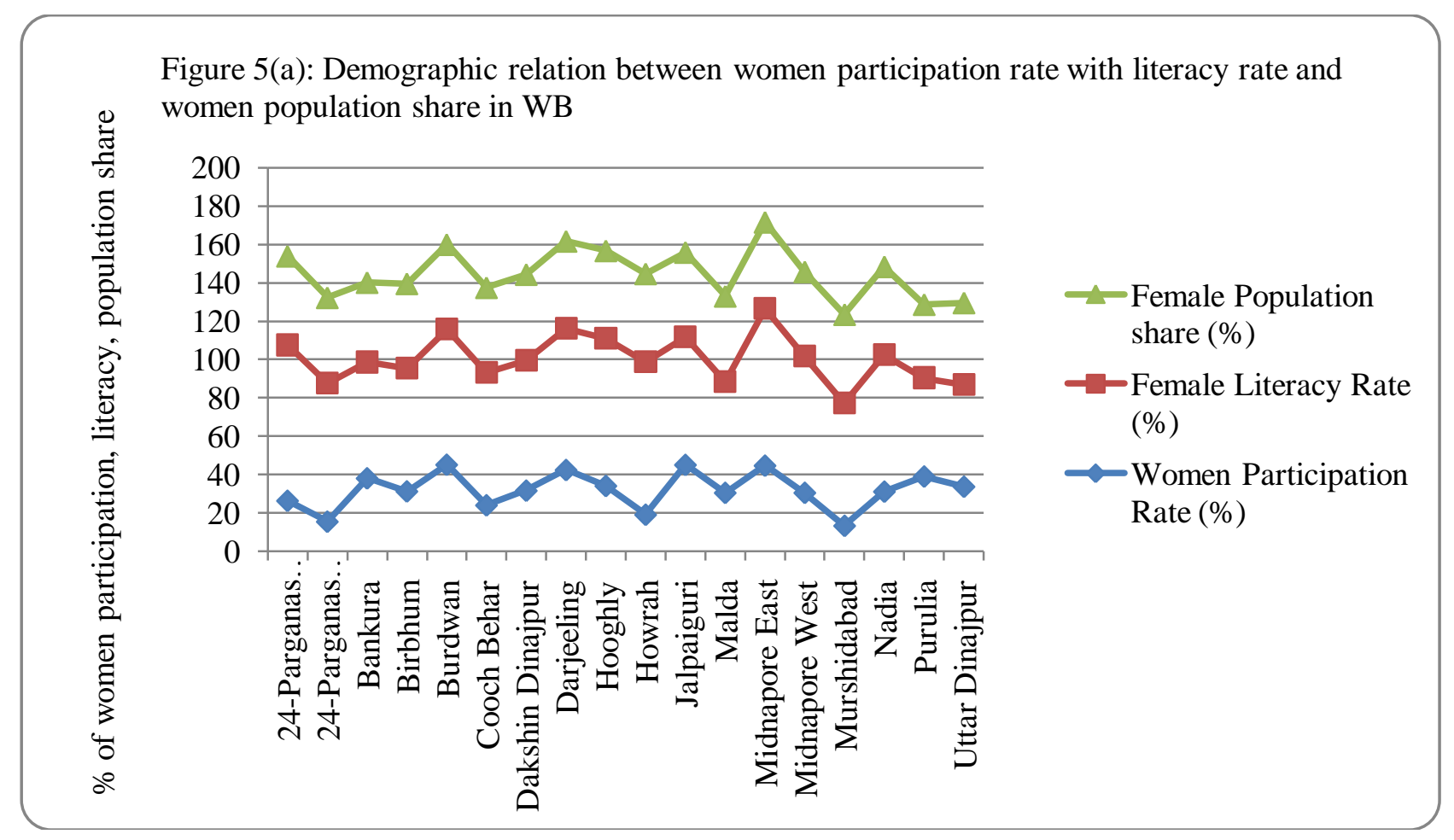

In Figure 5(a), we have measured percentage of women participation rate, female literacy rate and female population share on the vertical axis and leveled districts on the horizontal axis to find the relationship between them. The 
above figure shows that the districts which have more female population share and more literacy rate that districts have more female participation rate in MGNREGA. So we can say that literacy is playing a crucial role for women empowerment.

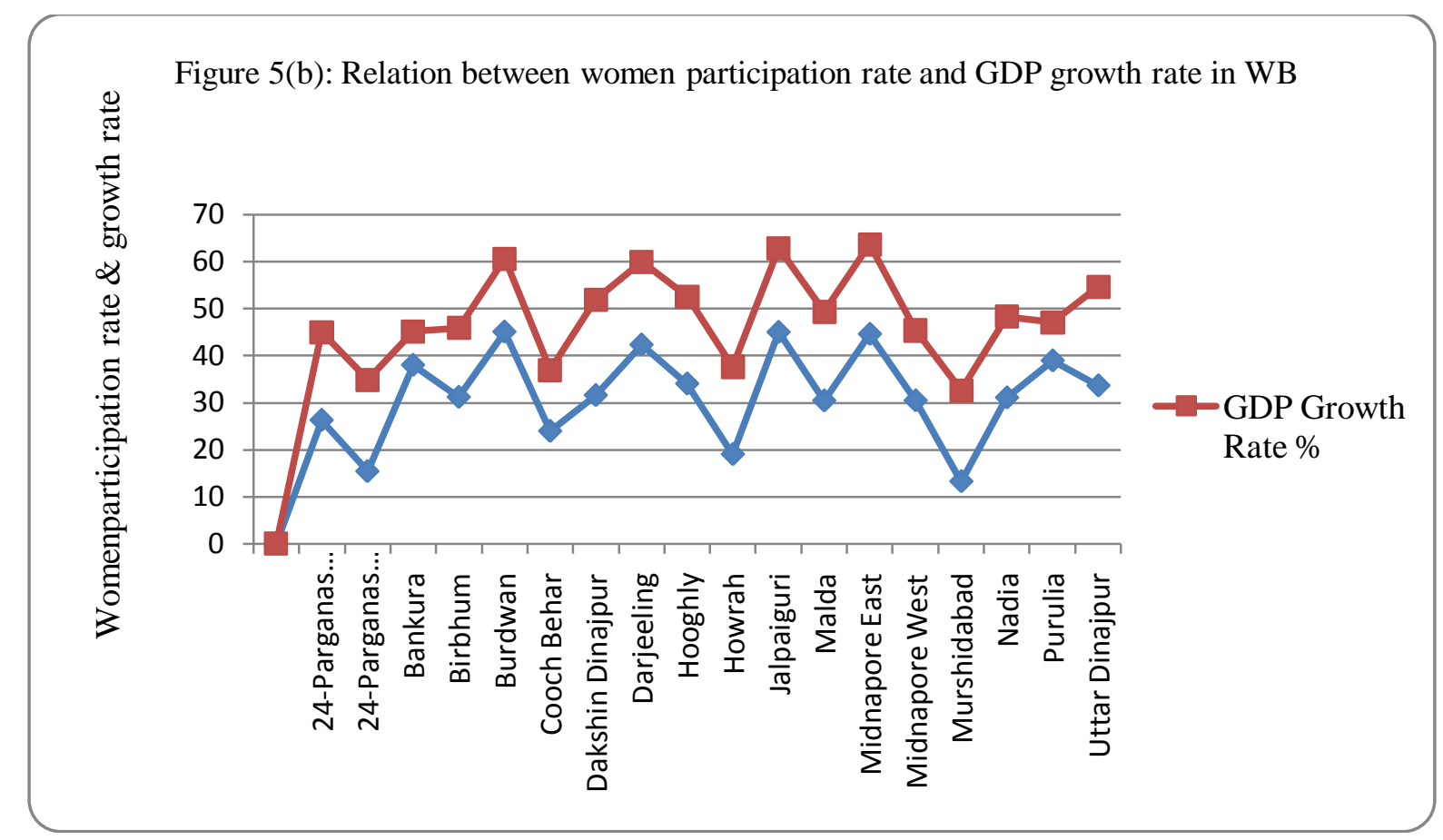

Again from the above Figure 5(b) it is clear that the GDP growth rate is high for the districts which have high women participation rate in MGNREGA.

Table 5(c):- Cluster Analysis.

\begin{tabular}{|l|c|c|c|c|c|}
\hline Cluster Membership & \multicolumn{5}{l|}{} \\
\hline Case & 6 Clusters & 5 Clusters & 4 Clusters & 3 Clusters & 2 Clusters \\
\hline 1:24-Parganas (North) & 1 & 1 & 1 & 1 & 1 \\
\hline 2:24-Parganas (South) & 2 & 2 & 1 & 1 & 1 \\
\hline 3:Bankura & 3 & 3 & 2 & 2 & 2 \\
\hline 4:Birbhum & 4 & 4 & 3 & 1 & 1 \\
\hline 5:Burdwan & 5 & 5 & 4 & 3 & 2 \\
\hline 6:Cooch Behar & 4 & 4 & 3 & 1 & 1 \\
\hline 7:Dakshin Dinajpur & 4 & 4 & 3 & 1 & 1 \\
\hline 8:Darjeeling & 5 & 5 & 4 & 3 & 2 \\
\hline 9:Hooghly & 5 & 5 & 4 & 3 & 2 \\
\hline 10:Howrah & 1 & 1 & 1 & 1 & 1 \\
\hline 11:Jalpaiguri & 5 & 5 & 4 & 3 & 2 \\
\hline 12:Malda & 6 & 3 & 2 & 2 & 2 \\
\hline 13:Midnapore East & 5 & 5 & 4 & 3 & 2 \\
\hline 14:Midnapore West & 4 & 4 & 3 & 1 & 1 \\
\hline 15:Murshidabad & 2 & 2 & 1 & 1 & 1 \\
\hline 16:Nadia & 4 & 4 & 3 & 1 & 1 \\
\hline 17:Purulia & 3 & 3 & 2 & 2 & 2 \\
\hline 18:Uttar Dinajpur & 6 & 3 & 2 & 2 & 2 \\
\hline
\end{tabular}


Table 5(d):- Cluster Matrix of districts of West Bengal.

\begin{tabular}{|c|c|c|c|c|c|c|c|}
\hline Cluster size & \multicolumn{6}{|c|}{ No. of Districts in each cluster } & Total \\
\hline & $\mathrm{I}$ & II & III & IV & $\mathrm{V}$ & VI & \\
\hline 2 Clusters & 9 & 9 & & & & & 18 \\
\hline 3 Clusters & 9 & 4 & 5 & & & & 18 \\
\hline 4 Clusters & 4 & 4 & 5 & 5 & & & 18 \\
\hline 5 Clusters & 2 & 2 & 4 & 5 & 5 & & 18 \\
\hline 6 Clusters & 2 & 2 & 2 & 5 & 5 & 2 & 18 \\
\hline
\end{tabular}

After the cluster analysis of distribution of the districts based on 4 parameters (women participation rate, female literacy rate, female population share and GDP growth rate) each, combined and all, we can conclude that 4 clusters is more appropriate because the distribution of the districts in each cluster is more even.

Table 5 (e):- List of Cluster Members.

\begin{tabular}{|c|c|c|c|c|c|}
\hline \multirow[t]{2}{*}{4 Clusters } & \multicolumn{5}{|c|}{ Cluster members with parameters } \\
\hline & District & $\begin{array}{l}\text { Women } \\
\text { Participation } \\
\text { Rate }(\%)\end{array}$ & $\begin{array}{l}\text { Female } \\
\text { Literacy Rate } \\
(\%)\end{array}$ & $\begin{array}{l}\text { Female } \\
\text { Population } \\
\text { share }(\%)\end{array}$ & $\begin{array}{l}\text { GDP Growth } \\
\text { Rate } \%\end{array}$ \\
\hline \multirow[t]{4}{*}{1} & 24-Parganas (North) & 26.27 & 81.05 & 46.47 & 18.69 \\
\hline & 24-Parganas (South) & 15.38 & 72.09 & 44.67 & 19.47 \\
\hline & Howrah & 19.01 & 79.73 & 45.85 & 18.61 \\
\hline & Murshidabad & 13.23 & 63.88 & 46.23 & 19.37 \\
\hline \multirow[t]{4}{*}{2} & Bankura & 37.99 & 60.44 & 41.62 & 7.12 \\
\hline & Malda & 30.41 & 57.84 & 44.65 & 18.93 \\
\hline & Purulia & 38.93 & 51.29 & 38.35 & 8.17 \\
\hline & Uttar Dinajpur & 33.62 & 53.15 & 42.68 & 21.02 \\
\hline \multirow[t]{5}{*}{3} & Birbhum & 31.17 & 64.07 & 44.17 & 14.69 \\
\hline & Cooch Behar & 23.93 & 69.08 & 44.37 & 12.98 \\
\hline & Dakshin Dinajpur & 31.56 & 67.81 & 44.85 & 20.33 \\
\hline & Midnapore West & 30.43 & 71.11 & 44.08 & 14.91 \\
\hline & Nadia & 31.05 & 71.35 & 45.89 & 17.22 \\
\hline \multirow[t]{5}{*}{4} & Burdwan & 45.06 & 70.47 & 44.32 & 15.47 \\
\hline & Darjeeling & 42.31 & 73.74 & 45.51 & 17.61 \\
\hline & Hooghly & 34.02 & 76.95 & 45.64 & 18.54 \\
\hline & Jalpaiguri & 44.99 & 66.65 & 44.12 & 17.85 \\
\hline & Midnapore East & 44.58 & 81.81 & 45.12 & 19.04 \\
\hline
\end{tabular}

After observing the above Table 5(e) we can say that $4^{\text {th }}$ number of the 4 clusters is more significant. Here the deviations of the each parameter between the cluster members are very less. We can also see that in this group women participation rate is more. Considering all the variables we can conclude that by increasing female literacy rate, women participation rate can be increased in this type of skill developmental program like, MGNREGA, which leads GDP growth rate also.

\section{Findings and Suggestions:-}

\section{Findings:-}

- Gender equality in participation in MGNREGA should be maintained properly

- Women participation rate has been increased in the last five years where male participation rate has been decreased in India as well as in West Bengal. Female participation rate is more than male participation rate in the present financial year

- There is a proportional change rate between total individual workers and total household workers in India as well as in West Bengal 
- Andhra Pradesh generates highest number of persondays in the current financial year followed by Tamil Nadu, Rajasthan, Telangana and Chattisgarh where Tamil Nadu was in the leading position for last four previous financial years (FY 2012-13 to FY 2015-16)

- The states like Telangana and West Bengal are maintaining an increasing trend significantly for the last five years

- In case of Union Territories no such kind of employment is demanded or even demanded, it's very less

- Most of the Panchayats in West Bengal ensure 100 days of employment to its registered members

- From this study, it is clear that most of the workers have saving a/c and this will enable for the economic development and women empowerment

- This scheme enhances social skills like communication, mobility, participation, decision making among women who participated in this scheme

- Female population share and Literacy rate is playing a vital role to empowering the rural women. The districts with high gender inequality and female literacy rate are doing very well in MGNREGA

- More women participation generates more GDP for the districts

\section{Suggestions:-}

- More initiation and awareness should be given to the rural poor women about MGNREGA, that they should know the benefits of the scheme which will increase the women participation rate

- Government should give more importance to productive works based on local need which will cover more women under the umbrella of MGNREGA

- Payments should be made on time

- More literacy driven programs should be arranged by the Govt. for the rural women, which will help them to involve themselves in such kind of scheme for their empowerment

- Govt. should give more importance and provide more work for the single women, widows and the old women

- As West Bengal is agriculture based economy so Govt. should provide more agricultural works for the state

- In states or districts where the scheme to be progressive, they need to continue to address higher order concerns such as conditions in the work place for women, childcare facility and women's participation in decision making processes locally

- In states or districts where women's participation is weak, some sort of administrative policies have to focus on enabling women to access work

- In MGNREGA worksites women are employed as unskilled labour over a longer period, the enhancement of skills and productivity through skill developmental programs will be one way of increasing earnings of women as well as empowerment

- Wage payment system through bank encourages savings but if the difficulties faced by the illiterate women in drawing cash from bank, provision can be made to provide door step delivery of the wages

\section{Conclusion:-}

McKinsey's Research Report (Noshir and Anu, 2016) indicated that as uncertainties cloud the global economic picture now, the International Monetary Fund has projected that India's GDP will grow by 7.4 percent for 2016-17, making it the world's fastest-growing large economy. Liberalization has created new opportunities. The challenge for policy makers is to manage growth so that it creates the basis for sustainable economic performance. Although much work has been done, India's transformation into a global economic force has yet to fully benefit all its citizens. Public policy and public works in India have generally tried to include women as a percentage of beneficiaries, but have not paid enough attention to gender sensitive design. The MGNREGA in its design has attempted some gender sensitivity. This is an act that guarantees 100 days of employment to all rural poor who attain the age of 18 with one third of women participation. Through this scheme Govt. expects socio-economic development and women empowerment. This research work is focused on the impact of MGNREGA on socio-economic development and women empowerment. From this study, it is clear that most of the Gram Panchayats (GPs) implemented it successfully in all the states as well as all the districts of West Bengal. Women workers are the major participants of this scheme. The main limitation of this study was the response from the women because this study is based on secondary data. On the basis of data collected from different sources for the study regarding this topic, it can be concluded that MGNREGA has a great role and impact on the rural development and women empowerment in coming future. Since the minimum wage paid under this program is far greater for rural women than the market agricultural wage for female workers, women who were not working previously have started to do so in MGNREGA sites. There seems to have been some 'smoothing' of income or consumption. According to 
McKinsey's Research Report (Noshir and Anu, 2016), though women now contribute only 17 percent of India's GDP and make up just 24 percent of the workforce (compared with 40 percent globally) but in the coming decade, they will represent one of the largest potential economic forces in the country. If it matched the progress toward gender parity of the region's fastest-improving country, it could add \$700 billion to its GDP in 2025 . Movement toward closing the gender gap in education and in financial and digital inclusion has begun in India, but there is scope for further progress.

\section{References:-}

1. ABN Kulkarni and K. S. Srinivasa Rao, "Savings and Investment Behaviour in India", Second All India Conference on Modelling Economic Behaviour and Policy held at Sri Satya Sai Institute of Higher Learning, Prasanthinilayam, 10-12, Dec. 2003

2. Brijesh Singh and K.S. Srinivasa Rao, "Pricing Strategies for Surviving an Economic Slowdown", National Conference on Services Management, Dayananda Sagar College of Management and Information Technology, Bangalore, India, 29-30, Oct. 2009

3. Dinesha, G. A., Mahesha, K. K., Kantharaja, B. B. and Shivanand Nari, (2015), "Inclusive Development and MGNREGA", Global Journal For Research Analysis, 4 (3). pp. 1-3. ISSN 2277 - 8160

4. Dutta, Subhabrata, "NREGA in West Bengal: Success and Challenges", Kurukshetra, Vol. 58, No.2, December 2009, pp 31-34

5. G. Gangadhara Rao, "MGNREGA and Changes in Rural Employment Trends, Wage Structure, and RuralUrban Migration", Arthshastra Indian Journal of Economics \& Research, Volume 3, Issue 5, SeptemberOctober 2014

6. Gupta S K; Ahmad Fearooz, "Asset Creation under MGNREGA”, International Journal of Management, IT and Engineering Vol.5, Issue 1, Jan. 2015, pp.275-283

7. Hazra Anupam,"NREGA: Transforming Rural India”,Kurukshetra, Vol. 58, No. 2, December 2009, pp 7-10

8. K T Karthika, "Impact of MGNREGA on Socio-Economic Development \& Women Empowerment", IOSR Journal of Business and Management (IOSR-JBM) e-ISSN:2278-487X, p-ISSN:2319-7668. Volume 17, Issue 7.2 July 2015, PP 16-19, www.iosrjournals.org

9. K.S. Srinivasa Rao and K. Srinivas Rao, "Measurement of City Size Mobility using Semi-Markov Models", XII Annual Conference of Indian Society of Probability and Statistics, Department of Mathematics \& Statistics, Cochin university of Science and Technology, Kochi, 09-12, Dec. 1991

10. Kar Spandita, "Empowerment of Women Through MGNREGAS: Issues and Challenges", Odisha Review-Feb.March 2013

11. Khera, R, "Employment Guarantee in Maharashtra and India", Report to UNDP, Regional Office, Delhi, 2005

12. Khera, Reetika and Nayak, Nandini, "Women Workers and Perceptions of the National Rural Employment Guarantee Act", Economic and Political Weekly, Vol. 44 No. 43, October 2009, pp 49-57

13. Mahapatra Richard, "How Women Seized NREGA", http://www.downtoearth.org.in/node/2282, 2010

14. MoRD, "National Rural Employment Guarantee Act 2005 (NREGA)", Report of the Second Year, April 2006March 2007, Ministry of Rural Development, Government of India, New Delhi

15. MoRD, "Mahatma Gandhi National Rural Employment Guarantee Act 2005: Report to People",February 2, 2011, Ministry of Rural Development, Government of India, New Delhi

16. Narayan Sudha and Das Upasak,"Employment Guarantee for Women in India Evidence on Participation and Rationing in the MGNREGA from the National Sample Survey", Indira Gandhi Institute of Development Research, Mumbai, June 2014, http://www.igidr.a.in/pdf/publication/WP-2014-017.pdf

17. Narayanan, S, "Employment Guarantee - Women's Work and Childcare", Economic and Political Weekly, Vol.49, No.9 March 2008, pp 10-13

18. Noshir Kaka and Anu Madgavkar, "India's Ascent: Five Opportunities for Growth and Transformation", Report of McKinsey's Global Institute, Aug. 2016

19. P.S. Srikantha Murthy and S. Indumati, "Economic Analysis of MGNREGA in the Drought-prone States of Karnataka, Rajasthan and Irrigation-dominated State of Andhra Pradesh", Agricultural Economics Research Review, Vol. 24, 2011, pp 531-536

20. Pankaj, A, and R Thanka, "Empowerment Effect of the NREGS on Women Workers: A Study in Four States", Economic and Political Weekly, Vol. XLV, No. 30, July 2010, pp 45-54

21. Poonia Jyoti, "Critical Study of MGNREGA: Impact and Women's Participation", International Journal of Human Development and Management Sciences, Vol. 1 No. 1, January-December 2012, ISSN: 2250-8714, www.journalshub.com 
22. Ramesh Gundeti and Kumar, T. Krishna, "Facet of Rural Women Empowerment-A Study in Karimnagar District in Andhra Pradesh", Kurukshetra, Vol. 58, No.2, December 2009, pp 29-30

23. Roy, Sanjay, "Impact of the Villagers in Tripura-Field Survey", Kurukshetra, Vol. 58, No.2, December 2009, pp 27-28

24. Sanjoy Roy, "Implementation of NREGS in Tripura: An Evaluation", The NEHU Journal, Vol VIII, No. 1, January 2010, pp.59-78

25. Shalini Nair, "Flagship scheme MGNREGA: Sustainability of a Turnaround", The Indian express, January 14, 2016

26. SharmaJogendra, "NREGA: Potential and Challenges", Kurukshetra, Vol. 58, No. 2, December 2009, pp 3-6

27. Sony Pellissery \& Sumit Kumar Jalan, "Towards Transformative Social Protection: A Gendered Analysis of the Employment Guarantee Act of India (MGNREGA)", Journal - Gender \& Development, Volume 19, Issue 2, 2011, pp.283-294

28. Surendra Singh, "MGNREGA: 100 days Employment Guarantee in Bundelkhand (M.P.)", International Journal of Management and Development Studies, Volume No. 2, Issue No. 4, 2013, (March) ISSN (Online): 2320-068 